\title{
An Unusual Chromosomal Aberration in a Case of Chediak-Higashi Syndrome
}

\author{
BURHAN SAY, ERGÜL TUNÇBILEK, BEHICE YAMAK, and SEVIM BALCI \\ From the Department of Pediatrics and the Clinical Genetics Laboratory, Hacettepe University, \\ Hacettepe Children's Hospital, Ankara, Turkey
}

Chediak-Higashi syndrome which appears to be a lysosomal disease (Douglas and Fudenberg, 1969; White, 1966) is characterized by partial albinism, photophobia, recurrent infections, hepatosplenomegaly, and a distinctive leucocyte anomaly (Chediak, 1952; Higashi, 1954). Available genetic and fine structural studies suggest that the condition is inherited as an autosomal recessive trait (Sadan $e t$ al., 1965; Douglas, Blume, and Wolff, 1969). Chromosome studies have been done in a few cases, but as expected have not shown any significant numerical chromosomal abnormalities (Kritzler et al., 1964; Rosenszajn et al., 1969). The condition does not seem to be confined to a particular population group, since patients with this syndrome have been reported from various parts of the world.

The purpose of this communication is to report a case of Chediak-Higashi syndrome from Turkey, in which chromosome studies revealed an unexpected and unusual abnormality in the form of partial monosomy for a $\mathrm{G}$ group chromosome (45,XY,G - / $46, \mathrm{XY} / 46, \mathrm{XY}, \mathrm{Gr})$.

\section{Case Report}

A 3-year-old boy was referred to us by his local physician with a history of recurrent infections of unknown aetiology (Fig. 1). His past history revealed that he had had an infection associated with a rash which was diagnosed as scarlet fever approximately one year previously, since when he had been treated for multiple episodes of diarrhoea and tonsillitis. Two weeks before his referral he was found to have enlarged submandibular and cervical glands associated with high fever and weight loss. The mother was 29 and the father 36 years of age, and there was no consanguinity between them. His 3month-old brother was reported to be in good health. A detailed family history revealed the presence of other members (with and without fair hair) who had photophobia.

Received 14 January 1970.

$8+$
Physical examination. The patient's height was $92 \mathrm{~cm}$. (10th centile), weight $14.5 \mathrm{~kg}$. (50th centile), and head circumference $49 \mathrm{~cm}$. (75th centile). He was pale, and acutely ill. His hair was light-coloured, in contrast to his parents' dark hair. The skin was dry, with slight desquamation, and there was horizontal nystagmus and photophobia in both eyes, which also had an antimongoloid slant. Other pertinent clinical findings included an enlarged left submandibular lymph node $(2 \times 1 \mathrm{~cm}$. in size), and multiple slightly enlarged lymph nodes over the axillary and inguinal areas. The liver was palpable 2.5 and the spleen $3 \mathrm{~cm}$. below the costal margins. Chest $x$-ray revealed pneumonia.

Laboratory findings. Routine haematological studies showed the patient's haemoglobin to be $7 \cdot 8 \mathrm{~g}$.l $100 \mathrm{ml}$., haematocrit $26 \%$, WBC $8600 / \mathrm{cu}$. mm., and reticulocyte count, $10 \cdot 2 \%$. Peripheral smears revealed hypochromia, anisocytosis, polychromasia, and poikilocytosis, and there were abundant thrombocytes. The most interesting finding was the presence of discrete

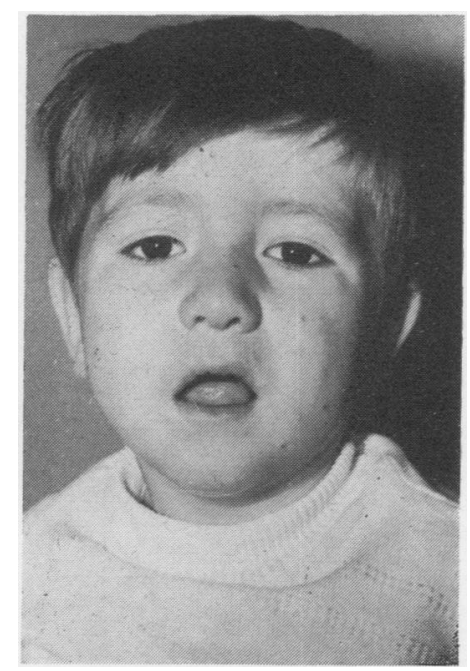

FIG. 1. The patient. 


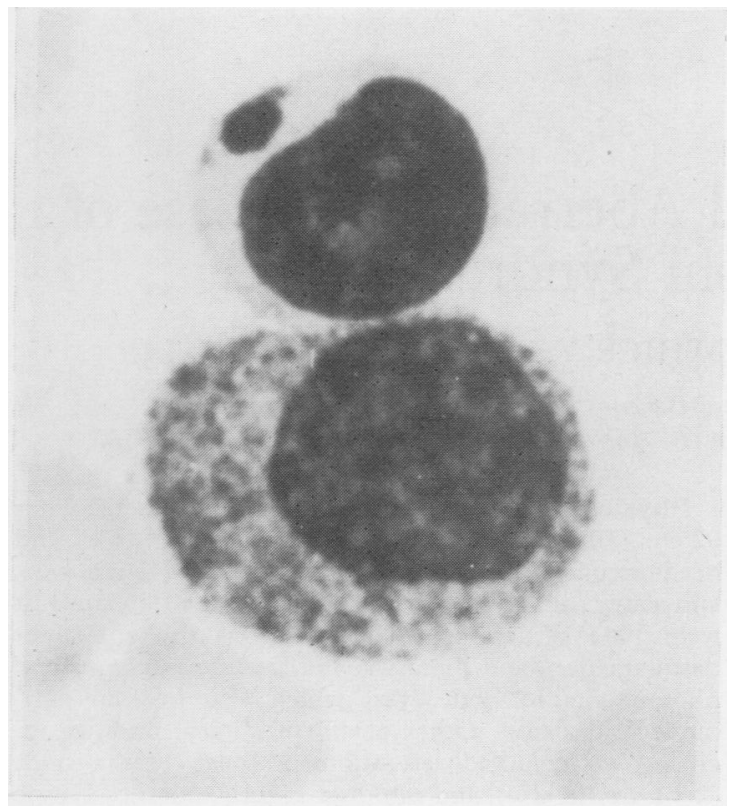

Fig. 2. Peripheral blood. ( $\times 1250$.

azurophilic inclusion bodies of various sizes in the cytoplasm of the lymphocytes as well as the polymorphonuclear leucocytes (Fig. 2). They were frequently round and occasionally irregular in shape. Repeated bonemarrow examinations revealed erythroid hyperplasia and eosinophilia, in addition to the inclusion bodies described above, in the lymphoid and myeloid cells. There were also many young myeloid cells with numerous vacuoles (Fig. 3), and smears obtained by splenic punctures revealed cells with similar inclusion bodies. No inclusions could be seen in the blood smears obtained from the parents, two grandparents, or a maternal aunt.

Cytogenetic investigations. Chromosome studies of the patient and his parents were made using cultures of peripheral blood, for which a modification of Moorhead et al.'s method (1960) was used. The chromosomes in 102 metaphase plates were counted and analysed, and in 19 of them a small acrocentric chromosome from the $\mathrm{G}$ group was missing. In all these latter plates, the Y chromosome could be clearly identified by its well-known morphological characteristics.

In a further 17 metaphase plates a minute ring chromosome, replacing a $\mathrm{G}$ chromosome, was present (Fig. 4). The remaining 62 plates showed 46 chromosomes, none of which had any structural abnormalities. An additional 4 plates showed inconsistent abnormalities. Chromosome studies of the parents revealed no abnormalities (Table I).

\section{Discussion}

Until recently, inborn autosomal monosomy in man was considered to be incompatible with life. The first case of complete monosomy for

\section{TABLE I}

CHEDIAK-HIGASHI SYNDROME: CHROMOSOME STUDIES

\begin{tabular}{c|r|r|r|rr|r}
\hline & 43 & 44 & 45 & \multicolumn{2}{|c|}{46} & 47 \\
\cline { 2 - 5 } & & $\mathrm{N}$ & $\mathrm{R}$ & 4 \\
\hline $\begin{array}{c}\text { 17 Jan. 1969 } \\
\text { 5 Feb. 1969 }\end{array}$ & -2 & - & 8 & 18 & 4 & - \\
\hline $\begin{array}{l}\text { Total } \\
(102)\end{array}$ & 2 & - & 19 & 64 & 13 & 2 \\
\hline
\end{tabular}

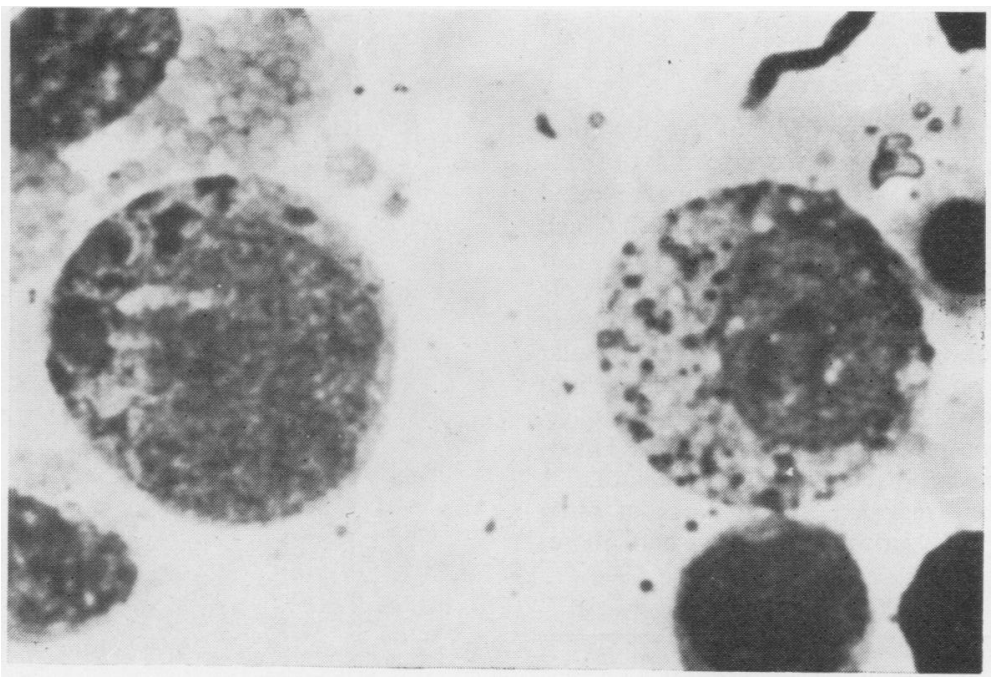

FIG. 3. Bone-marrow. A cell with multiple inclusion bodies. $(\times 1250$. $)$ 

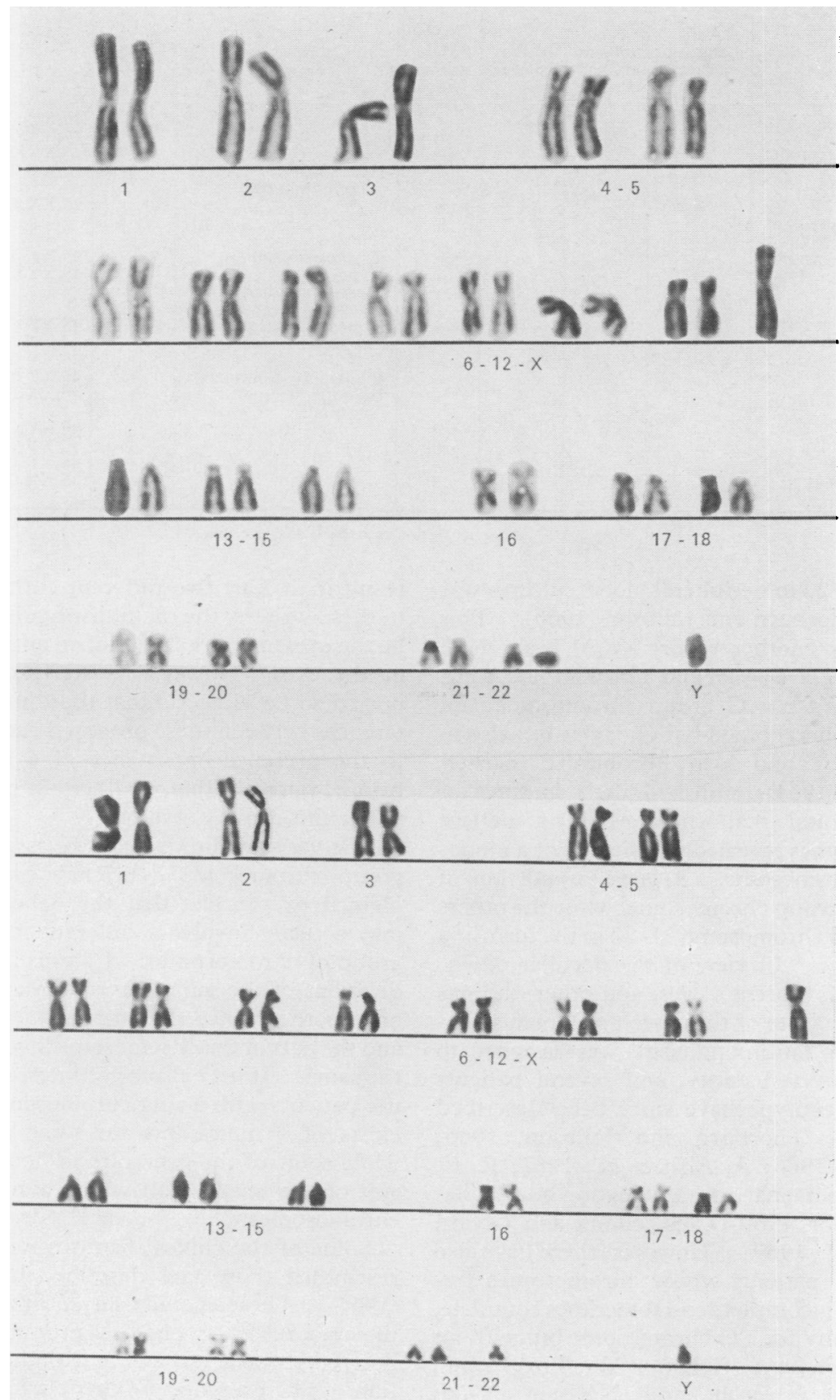

FIG. 4. Karyotypes showing a minute ring chromosome from group 21-22 (above) and a chromosome missing from the same group (below). 
TABLE II

CASES ASSOCIATED WITH DEFICIENCIES OF G GROUP OF CHROMOSOMES

\begin{tabular}{|c|c|c|c|c|c|c|c|}
\hline Authors & $\begin{array}{l}\text { Anti- } \\
\text { mongoloid } \\
\text { Slant }\end{array}$ & $\begin{array}{l}\text { Pro- } \\
\text { minent } \\
\text { Nasal } \\
\text { Bridge }\end{array}$ & $\begin{array}{l}\text { Micro- } \\
\text { gnathia }\end{array}$ & $\begin{array}{l}\text { Low-set } \\
\text { Mal- } \\
\text { formed } \\
\text { Ears }\end{array}$ & $\begin{array}{l}\text { Genito-urinary } \\
\text { System }\end{array}$ & $\begin{array}{l}\text { Mental } \\
\text { retard. }\end{array}$ & Chromosomes \\
\hline $\begin{array}{l}\text { Lejeune et al. (1964) } \\
\text { Penrose (1966) } \\
\text { Thorburn and Johnson (1966) } \\
\text { Reisman et al. (1967) }\end{array}$ & $\begin{array}{l}+ \\
+ \\
+ \\
+\end{array}$ & $\begin{array}{l}- \\
+ \\
0 \\
+\end{array}$ & $\begin{array}{l}+ \\
+ \\
+ \\
+\end{array}$ & $\begin{array}{l}+ \\
0 \\
+ \\
+\end{array}$ & $\begin{array}{c}\text { Hypospadias } \\
0 \\
- \\
\text { Hypospadias, }\end{array}$ & $\begin{array}{l}+ \\
+ \\
+ \\
0\end{array}$ & $\begin{array}{l}\text { 45,XY,G - / } 46, X Y, G q- \\
\text { 46,XX,Gr } \\
\text { 45,XX,G- } \\
46, X Y, G q-\end{array}$ \\
\hline $\begin{array}{l}\text { Al-Aish et al. (1966) } \\
\text { R. C. Hindle (1969) (personal } \\
\text { communication to Challa- }\end{array}$ & + & - & - & + & - & + & $45, \mathrm{XX}, \mathrm{G}-$ \\
\hline $\begin{array}{l}\text { combe and Taylor, (1969)) } \\
\text { Challacombe and Taylor (1969) }\end{array}$ & + & + & $\begin{array}{l}+ \\
+\end{array}$ & $\stackrel{+}{+}$ & $\begin{array}{l}\text { Cryptorchidism } \\
\text { Hypospadias, } \\
\text { cryptorchidism, } \\
\text { inguinal hernia }\end{array}$ & $\begin{array}{l}+ \\
+\end{array}$ & $\begin{array}{l}45, X y, G-, \text { ace } \\
45, X Y, G-/ 46, X Y, G r\end{array}$ \\
\hline Endo et al. (1969) & ? & 0 & - & + & $\begin{array}{l}\text { Hypospadias, inguinal } \\
\text { hernia, scrotal dysp. }\end{array}$ & + & $45, X Y, G-/ 46, X Y, G q-$ \\
\hline $\begin{array}{l}\text { Present case } \\
\text { Cohen (1966) } \\
\text { Engel et al. (1966) }\end{array}$ & $\begin{array}{l}+ \\
-\end{array}$ & $\begin{array}{l}+ \\
-\end{array}$ & $\begin{array}{l}\overline{0} \\
+\end{array}$ & $\begin{array}{l}+ \\
+ \\
-\end{array}$ & $\begin{array}{l}\text { Bilateral hydroureters } \\
\text { Infantile external }\end{array}$ & $\begin{array}{l}+ \\
+ \\
+\end{array}$ & $\begin{array}{l}\text { 45,XY,G - } / 46, X Y, G r / 46, X Y \\
45, X Y, G-/ 46, X Y \\
46, X X, B p-, G q-\end{array}$ \\
\hline $\begin{array}{l}\text { McIlree et al. (1966) } \\
\text { Reisman et al. (1967) } \\
\text { Weleber et al. (1968) } \\
\text { Blank and Lorber (1969) }\end{array}$ & $\begin{array}{l}- \\
\overline{-} \\
-\end{array}$ & $\begin{array}{l}0 \\
0 \\
0\end{array}$ & $\begin{array}{l}0 \\
0 \\
0\end{array}$ & $\begin{array}{l}0 \\
0 \\
+ \\
0\end{array}$ & $\begin{array}{c}0 \\
0 \\
\frac{0}{0}\end{array}$ & $\begin{array}{l}0 \\
+ \\
+ \\
+\end{array}$ & $\begin{array}{l}\text { 46,XY,Gr } \\
46, X Y, G q- \\
46, X X, G r \\
45, X X, G-/ 46, X X, G r\end{array}$ \\
\hline
\end{tabular}

+, Present; -, Absent; 0, not recorded; ace, acentric.

chromosome 21-22 in peripheral blood cultures was described by Thorburn and Johnson (1966). This was followed by another report by Al-Aish et al. (1967) describing a $4 \frac{1}{2}$-year-old girl who had complete monosomy for a $G$ group chromosome, not only in the peripheral blood lymphocytes but also in the bone-marrow and skin fibroblasts. Earlier, Lejeune et al. (1964) published their findings of multiple congenital malformations in a patient whose chromosomes revealed mosaicism for a monosomy 21-22 chromosome. A large proportion of cells lacked a $\mathrm{G}$ group chromosome, while the others showed a deleted chromosome 21-22 in the form of a ring chromosome. In view of the peculiar downward slant of this patient's eyes, and other findings that were the opposite of those seen in Down's syndrome, the term 'antimongolism' was assigned to this newly discovered entity, and several patients with similar phenotype have since been described (Penrose, 1966; Thorburn and Johnson, 1966; Reisman et al., 1966; Al-Aish et al., 1967; R. C. Hindle, 1969, personal communication to Challacombe and Taylor (1969); Challacombe and Taylor, 1969; Endo et al., 1969). However, there have also been reports of patients whose chromosomes frequently showed incomplete and sometimes complete, inborn monosomy for a $\mathrm{G}$ chromosome but without antimongoloid features (Cohen, 1966; Engel et al., 1966; McIlree, Tulloch, and Newsam, 1966; Reisman et al., 1967; Weleber, Hecht, and Giblett, 1968; Blank and Lorber, 1969) (Table II). This prompted Weleber et al. (1968) to suggest that partial or complete absence of a G chromosome may result in at least two different entities. According to these writers, the main distinguishing factor may be the presence or absence of an antimongoloid slant in the eyes. However, a study of the cases reported so far suggests that there may be other differences between these proposed entities with regard to the presence or absence of a prominent nasal bridge, micrognathia, and certain malformations of the genito-urinary system.

The varying clinical features associated with a $G$ group chromosome deficiency can easily be explained by the fact that the deficiencies observed may actually involve a different member of the $G$ group of chromosomes. Likewise, even cases with deletions of the same chromosome may differ from one another, since the amount of deleted material, and the part of the chromosome involved, may not be the same. It may also be of interest to note that for the patients with a ring chromosome the possibility exists of a monosomy for some genetic material, while some of the genes are in double dose as a result of the misdivision which is observed in these chromosomes.

Some of the clinical features seen in our patient resembled those first described by Lejeune et al. (1964). These include an antimongoloid slant of the eyes, relatively big ears, prominent root of nose, delayed physical growth, and slight mental retardation. The presence of other clinical and laboratory findings typical of the syndrome described by Chediak and Higashi is, of course, of further interest. Since it is generally accepted that this syndrome is inherited as an autosomal recessive 
trait, and also that the chromosome studies of these patients have so far revealed no similar abnormalities, it is quite likely that the unusual chromosomal abnormality seen in our case is coincidental, though in a recent study chromatid and chromosomal breakages, elongated chromosomes, and heteropycnotic gaps were found (Rosenzajn et al., 1969). On the other hand, it should be emphasized that only a few cases of Chediak-Higashi syndrome have been investigated for chromosome abnormalities, and detailed reports on leucocyte morphology in patients with antimongolism are lacking. For this reason it is hoped that our paper will prompt other workers to report whether or not any relation exists between the loss of genetic material from a $G$ group chromosome and the clinical and laboratory findings seen in patients with Chediak-Higashi syndrome.

Finally it should be remembered that patients with this condition have a high incidence of lymphoreticular malignancy, and acquired monosomy G has been reported in acute myeloblastic leukaemia (Sandberg et al., 1964), in the terminal stage of the Di Guglielmo syndrome (Castoldi et al., 1968), and in a case of refractory sideroblastic anaemia with leukaemic transformation (Silberman and Krmpotic, 1969). This indicates that follow-up of our case would be of interest to see whether or not malignant transformation occurs at an early age.

\section{Summary}

A 3-year-old boy with Chediak-Higashi syndrome is described. Chromosomal analyses interestingly revealed a partial monosomy of the chromosome 21 . The possible aetiological significance of this unusual chromosome aberration is discussed.

\section{REFERENCES}

Al-Aish, M. S., de la Cruz, F., Goldsmith, L. A., Volpe, J., Mella, G., and Robinson, J. C. (1967). Autosomal monosomy in man. Complete monosomy $\mathrm{G}(21-22)$ in a four-and-one-half-year-old mentally retarded girl. New England fournal of Medicine, 277, 777-784.

Blank, C. E., and Lorber, J. (1969). A patient with 45,XX,G-1 46,XX,Gr mosaism. Fournal of Medical Genetics, 6, 220-223.

Castoldi, G., Yam, L. T., Mitus, W. J.. and Crosby, W. H. (1968). Chromosomal studies in erythroleukemia and chronic erythremic myelosis. Blood, 31, 202-215.
Challacombe, D. N., and Taylor, A. (1969). Monosomy for a G autosome. Archives of Disease in Childhood, 44, 113-119.

Chediak, M. (1952). Nouvelle anomalie leucocytaire de caractère constitutional et familial. Revue d'Hématologie, 7, 362-371.

Cohen, M. M. (1966). Chromosomal mosaicism associated with a case of cyclopia. Fournal of Pediatrics, 69, 793-798.

Douglas, S. D., Blume, R. S., and Wolf, S. M. (1969). Fine structural studies of leukocytes from patients and heterozygotes with the Chediak-Higashi syndrome. Blood, 33, 527-540.

$\longrightarrow$, and Fudenberg, H. H. (1969). Chediak-Higashi syndrome. Medical Clinics of North America, 53, 914-922.

Endo, A., Yamamoto, M., Watanabe, G.-I., Suziki, Y., and Sakai, K. (1969). 'Antimongolism' syndrome. British Medical fournal, 4, 148-149.

Engel, E., Hastings, C. P., Merrill, R. E., McFarland, B. S., and Nance, W. E. (1966). Apparent cri-du-chat and 'antimongolism' in one patient. Lancet, 1, 1130-1132.

Higashi, O. (1954). Congenital gigantism of peroxidase granules. The first case ever reported of qualitative abnormity of peroxidase. Tohoku fournal of Experimental Medicine, 59, 315-332.

Kritzler, R. A., Terner, J. Y., Lindenbaum, J., Magidson, J., Williams, R., Preisig, R., and Phillips, G. B. (1964). ChediakHigashi syndrome. Cytologic and serum lipid observations in a case and family. American fournal of Medicine, 36, 583-594.

Lejeune, J., Berger, R., Réthoré, M. O., Archambault, L., Jérôme, H., Thieffry, S., Aicardi, J., Broyer, M., Lafourcade, J., Cruveiller, J., and Turpin, R. (1964). Monosomie partielle pour un petit acrocentrique. Comptes Rendus Hebdomadaires des Séances de l'Académie des Sciences, 259, 4187-4190.

McIlree, M. E., Tulloch, W. S., and Newsam, J. E. (1966). Studies on human meiotic chromosomes from testicular tissue. Lancet, 1 , 679-682.

Moorhead, P. S., Nowell, P. C., Mellman, W. J., Battips, D. M., and Hungerford, D. A. (1960). Chromosome preparations of leukocytes from human peripheral blood. Experimental Cell Research, 20, 613-616.

Penrose, L. S. (1966). Anti-mongolism. Lancet, 1, 497.

Reisman, L. E., Darnell, A., Murphy, J. W., Hall, B., and Kasahara, S. (1967). A child with partial deletion of a G-group autosome. American fournal of Diseases of Children, 114, 336-339.

- Kasahara, S., Chung, C. Y., Darnell, A., and Hall, B. (1966). Anti-mongolism, studies in an infant with a partial monosomy of the 21 chromosome. Lancet, 1, 394-397.

Rosenszajn, A. L., Radnai, J., Tatarski, A., and Benderlei, A. (1969). Blood cell culture and chromosomal findings in Chediak-Higashi syndrome (Abst.). Israel fournal of Medical Sciences, 5, 1087.

Sadan, N., Yaffe, D., Rozenszajn, L., Adar, H., Soroker, B., and Efrati, P. (1965). Cytochemical and genetic studies in four cases of Chediak-Higashi-Steinbrinck syndrome. Acta Haematologica, 34, 20-29.

Sandberg, A. A., Ishihara, T., Kikuchi, Y., and Crosswhite, L. H. (1964). Chromosomal differences among the acute leukemias. Annals of the New York Academy of Sciences, 113, 663-716.

Silberman, S., and Krmpotic, E. (1969). Refractory anemia with leukemic transformation and chromosomal change. A case report. Acta Haematologica, 41, 186-192.

Thorburn, M. J., and Johnson, B. E. (1966). Apparent monosomy of a $\mathrm{G}$ autosome in a Jamaican infant. Fournal of Medical Genetics, 3, 290-292.

Weleber, R. G., Hecht, F., and Giblett, E. R. (1968). Ring-G chromosome, a new G-deletion syndrome? American fournal of Diseases of Children, 115, 489-493.

White, J. G. (1966). The Chediak-Higashi syndrome: a possible lysosomal disease. Blood, 28, 143-156. 